\title{
THE REPRESENTATION OF THE EUROPEAN UNION IN THE DISCUSSION HELD BY THE LOWER CHAMBER OF THE POLISH PARLIAMENT ON THE MIGRATION CRISIS IN EUROPE
}

Krzysztof CEBUL, PhD

Institute of Political Science and Public Administration, Cardinal Stefan Wyszynski University in Warsaw, Poland

\begin{abstract}
The article uses the discourse analysis to recreate the images of the European Union unfolded from the debate held in the Lower Chamber of the Polish Parliament on $16^{\text {th }}$ September 2015 on the information concerning the migration crisis in Europe and its repercussions for Poland, as presented by the Prime Minister. In the analysis the author adopted some methodological assumptions allowing him to capture the relationship between discourse and political practice. The author also emphasizes the significance of contextual framework as a requirement for reconstructing the discourse. The analysis points out the relative stability of divisions within the Polish integration discourse. The above-mentioned dichotomy was recreated using the following categories: (1) modified sovereignty and (2) self-determination (independence in decision-making). The article also stresses the continuation of this division within the analyzed debate, in which the following collective categories were distinguished: 1) the EU as a solidarity community and 2) the EU as the area of antagonized national interests.
\end{abstract}

Keywords: Poland, the European Union, parliamentary discourse, migration crisis, solidarity, community, rivalry, particularism.

\section{Introduction}

The aim of this article is to recreate (reconstruct) the meanings - the ways in which the Polish Members of Parliament perceived the European Union (EU) in the debate held in the Lower Chamber of the Polish Parliament on $16^{\text {th }}$ September 2015 in regard to the information on the 
migration crisis in Europe and its repercussions for Poland, presented by the Prime Minister (Speeches, 2015).

The choice of the debate is by no means accidental. The migration crisis in Europe (2015) was one of the landmarks of the European Union crisis. Among the causes of the EU crisis one must list, inter alia, its internal systemic dysfunctions (manifested, for example, in its inability to act effectively in managing risk), originating in the course (scope) of the integration process so far. The inter-governmental dimension turned out to be the most sensitive and problematic issue for the efficiency of the EU as a whole (cf. Fehler, Cebul, Podgórzańska, 2017, pp. 173-174). The crisis fully demonstrated the power of particularisms, which can therefore be analyzed as characteristic elements hampering the integration process. As a result of the crisis, the importance of the EU internationally deteriorated (cf. Adamczyk, 2017, pp. 308-312). Therefore, it is assumed that the analysis of the above-mentioned parliamentary discussion, due to the significance of the moment for the EU - will allow us to reveal cognitively interesting constructions (different points of view) that will expand our knowledge on conditions and shape of the integration discourse in Poland.

\section{The methodological assumptions of the discourse analysis}

The research will be based on the discourse analysis method. Because of the ambiguity of this approach (cf. Szacki, 2002, p. 905), it seems necessary to make a few assumptions which will allow us to determine the scope (the possibilities) of discourse analyses. The analysis of the political or parliamentary discourse stands for attempts aimed at determining what images and meanings are created at the level of language practices (Rapley, 2010, p. 23). It should be noted, however, that the discourse assessment is disturbed by the ambiguity of the relationships between the object and its meaning. These limitations also stem from the fact that each person is involved in some language reality. Therefore, it is impossible to take a position outside discourse, as one cannot avoid subjectivity.

For the purpose of research it is assumed that the discourse is an event generalized by the political system and simultaneously generating its verbal and non-verbal significance (Rittel, 2005, p. 24). Although discourse analyses mainly concern the level of language practices, one cannot overlook the importance of communication process functions in a social system. Language cannot be isolated from the system as it is not a world in itself, automatically reproducing and updating 
itself for some unknown reason. People try to recognize and understand complex existential situations and take specific actions, thus transferring their experiences onto the language level. This relationality of experience and language demonstrates the ontological condition of reference, as something that is linguistically recognized must exist somehow. To put it differently something must exist in order to be identified (Ricoeur, 1989, p. 91). Therefore, it must be presumed that the language carries some, rather ambiguous, interpretation of the being (cf. Maurin, 1978, p. 7).

And although the relationship between the language of politics and political action may adopt various forms (which surely increases uncertainty as to the course of the relationship in this scope), it is worth paying attention to the observable relationship between language and the occurrence of particular political reality (cf. Waśkiewicz, 1998, p. 86). The existence of such relationship is confirmed by concepts and visions, known as ideation practices, consisting in projecting the desired political order (cf. Paruch, Trembicka, 2002, p. 8). Such concepts clearly constitute the emanation of the political awareness of a heterogeneous community. They are as diverse as the community itself. This means that they constitute an integral part of political life and as such, they must be granted the status of facts (Waśkiewicz, 1998, p. 87).

Yet another issue is to what extent discourse analyses enable us to explain complex decision processes. On one hand the official nature of speeches during parliamentary debates may be a kind of a veil for what is happening behind the scenes, where, in the absence of observers, some key decisions might be taken. On the other hand, it is during the parliamentary debates based on the rivalry between those in majority and the opposition that the permanent confrontation and negotiation of the meanings of the political language take place. In such conditions these meanings continuously update by reproducing, determining modified or new concept frameworks and reference points. The intensity of polarization of the parliamentary discourse and the considerable scope of involvement of debate participants are explanatory for how significant the meanings revealed by discourse analyses are. Thus the representative bodies play a special role in the power system. Their power stems from transparence that is unmatched by other institutions, transparence which yields them to considerable social pressure. Finally, they ensure the balance of social interests. However, this function can be performed only when there is opposition able to disturb the government. Thanks to the possibility of correcting and questioning the discourse of those in power, one party cannot own the discourse exclusively (Waśkiewicz, 2012, p. 277). Also in the 
parliament, due to the possibility of polarization, the pressure of those in power to establish the rule of unity is, at least partially, overcome. Thus it constitutes an arena on which the political dispute is led.

It should be indicated that it is possible to analyze the discourse only when we know its context. Context can be defined as a specific system within which discourse-creating communications function. These communications are derivatives of the system, shaping it simultaneously. Context must be considered both in its narrower representation - from the angle of determinants of the parliamentary debate; and in its broader representation - taking into account relatively permanent factors determining the course of the process of Poland's integration with the European Union. While no one questions the statement that the text depends on the circumstances in which it was written and read (or uttered), it is incredibly difficult (as we have already shown) to capture this dependence (Waśkiewicz, 1998, p. 89). Nevertheless, we should always tie the area of the inquiry into language communication conducted within the discourse analysis with the nontextual dimension (Duszak, 1998, p. 13), as the reference point in a discourse analysis does not lie in language, but somehow outside the sentences (though it is by no means separated from them) and draws our attention to the process of discourse organization, namely to the frameworks in which meanings are created. These meanings have some driving force concerning the modification of such frameworks. Therefore, it is justifiable to talk of mutual and close interdependence of the system features and the features generated in the area of text influence (Grzegorczykowa, 1998, p. 38). This interdependence indicates that the analysis of the discourse, namely interrelated sequences of language behaviors, determining and determined by a broadly understood communication situation (context), allows us to identify the goals that the discourse participants hope to achieve. Therefore they should be perceived as the announcement of specific actions (cf. Laskowska, 2004, p. 14; Rittel, 2005, p. 45).

A relatively comprehensive approach to this issue is offered by the concept of social constructivism. Its fundamental assumption lies in critical approach to knowledge and concepts considered to be obvious, while assuming that people's knowledge of the world is not accidental, as it is determined by permanent indicators (which need to be sought in history and culture). Critical reflection (deconstruction of paradigms) constitutes the ground on which it is possible to reconstruct the context. The knowledge of the context determines the possibility of understanding the text and decoding its meanings (interpretation). As far as participants of the communication 
process are concerned, their involvement in the context is only natural. However, a researcher is outside a particular communication process, thus being outside context. It should be noted that the functional dimension of discourse analysis (possibilities of encoding and reconstructing) boils down to finding a level which will allow us to capture fundamental determinants of shades of meanings included in communications. According to social constructivism assumptions, this knowledge is generated, maintained and updated during social processes; therefore thought and action are connected by means of feedback, which, in turn, directs us towards seeking interdependencies between them (cf. Rapley, 2010, pp. 25-26).

The statement claiming that the social world is socially constructed is equal to acknowledging the interdependence between the meaning and materiality, which means that discourse is the driving force in the process of Poland's integration with the European Union, as well as in the perceived processes of integration and disintegration within the European space. By adopting this assumption, we assume that all aspects of the European integration process concentrate around a specific, central dialectic axis, for which the following categories and constitutive: 1) origin, 2) consolidation, 3) reproduction and 4) transformation of social phenomena within the scope of its influence (cf. Faircloug, Duszak, 2008, p. 8).

Thus, since all political institutions are human-made, even this basic circumstance indicates that it is possible to cognize them rationally, whereas the susceptibility to change demonstrated by materialized political creations only confirms creational capacities of the thought. Without such reflection they would have to be static and external, and as such, they would be inaccessible to the society (Waśkiewicz, 1998, p. 13). Therefore, the possibility of creating and transforming clearly demonstrates the power of a word. A speech is a specific form of reflecting this as well as the only available form of expression in which our existential situation materializes in a particular way. This image is not and cannot be coherent, since oppositions and differences of the appearing messages (their contradiction and ambiguity) constitute an inevitable product of communication (cf. Fleischer, 2005, p. 132).

The election to the Lower and Higher Chamber of the Parliament, held on $9^{\text {th }}$ October 2011, gave Platforma Obywatelska (Civic Platform, PO) 207 seats, making the party once again the election winner. Prawo i Sprawiedliwość (Law and Justice, PiS) won 157 seats, Ruch Palikota (Palikot Movement, RP) won 40 seats, Polskie Stronnictwo Ludowe (Polish People's Party, PSL) 
- 28 seats, Sojusz Lewicy Demokratycznej (Democratic Left Alliance, SLD) - 27 seats. One seat was taken by the German minority (Election outcomes. 2011). PO and PSL once again formed a coalition government (in 2007-2011 the government was also formed by the PO-PSL coalition). It should be noted that in 2007-2011 and 2011-2015 parliamentary discourse was dominated by the vision of the conciliatory European Union. On the other hand, after the parliamentary election of $28^{\text {th }}$ October 2015 (Election outcomes, 2015), won by PiS (on its election lists there were also candidates from Poland Together and Solidarity Poland), this vision was abandoned and the concept of self-determination was revived (it had been implemented earlier in 2005-2007, initially in the minority government formed by PiS, then in the coalition of PiS, League of Polish Families and Self-Defense of the Republic of Poland). Also, in the next parliamentary election, held on $13^{\text {th }}$ October 2019, PiS won again (Election outcomes, 2019).

The debate held on $16^{\text {th }}$ September 2015 (Speeches, 2015) reveals the dichotomy in the way the European Union is perceived and how the relations between Poland and the EU are seen by representatives of the main parties in the Parliament. In an attempt to find relatively broad and general categories we can distinguish two opposing images of the European Union that appeared in the discussion, namely: 1) as a solidarity community (this image was mostly presented by PO) and 2) as antagonized national interests (as perceived mainly PiS). It should also be noted that this dissonance is by no means temporary. We can point at a relatively permanent division concerning the European Union matters among representatives of the main political powers in Poland, manifested in two totally different ways of perceiving the integration process.

The impact of the migration crisis should not be perceived as the cause of the crack described in the next part of the article. There is no doubt, however, that influenced by the modifying pressure of the crisis, the above-mentioned relatively permanent polarization system is being updated through the confrontation of different paradigms and, thus, it is being reinforced (deepened). The migration crisis context provides particular sides of the political conflict with justification for the constructs they believe in, thus emphasizing the dichotomy.

As described above, the dispute evolving around the migration crisis has its own place in the battle between two different visions of Poland's participation in the integration process, so visible in the Polish parliamentary discourse. In the first case (this stand has been adopted by PO, PSL and SLD), we observe a modified way of understanding sovereignty (independence) (cf. Cebul, 2018, p. 432). A typical element of this structure lies in the starting point, which is not the 
category of national interest referring to a given state. The new concept of national interest, modified in the process of Europeanization (as a result of the EU pressure that Poland experienced when applying for the membership), includes the integration space, that is the structure of ties between the EU countries. These ties are treated as a specific system of connected vessels. In this approach, sovereignty is moved from the level of a country to the level of the European Union. Thus, we have here supranational sovereignty (cf. Czachór, 2006, p. 78). As a result of this shift, Poland's interest is each time considered (weighed) from the point of view of interests of the major EU players, perceived as integration leaders. The necessity to remain in the main integration flow is tantamount to the possibility of maintaining the entity status by Poland. Moreover, it allows us to build the image of the conciliatory European Union, to perceive the EU as a whole (the unanimous European Union, phasing out internal contradictions, thus the EU which is an area of security). This direction is also characterized by the belief that the advancing integration process actually contributes to eliminating particularisms within the European Union. This means that the interests of particular EU countries, as a result of Europeanization, become similar and gradually merge. The integration progress, therefore, is not seen as a threat to Poland's sovereignty, but it is treated as a factor that strengthens Poland, all member states and the European Union. This way of perceiving integration is additionally reinforced by the belief that it is objectively necessary to maintain the European integration as there is no alternative to it. This leads to the absolute requirement to maintain unanimity in the European Union, while all particular interests are treated as potential dangers to the integration process, which may, in the long run, lead to breakdown and disintegration.

In the second case (this position is represented mainly by PiS), the principle that explains the EU reality is the category of self-determination - decision independence, drawn directly from the classic concept of sovereignty - (cf. Cebul, 2018, pp. 432-333). What is interesting in this approach to perceiving the European Union is that the integration process is treated as a binding necessity. This lack of choice (lack of another path) paradoxically seems to be the source of specifically understood certainty in regard to the durability of the EU project. According to the self-determination concept, the only authorized entity having decision powers within a specific scope of matters is the state exclusively. The state itself becomes a reference point, which, in turn, leads to an increased degree of inconsistency with the environment. The European Union is mainly perceived as the space in which separate (particular) interests clash. It is generally seen as a place 
of rivalry, a fight between particular states that want to win control over other states. Therefore, all postulates assuming further deepening of the integration process are interpreted only as attempts of other entities - aimed at permanently limiting the creation capacities (potential) of the country, gradually leading to the loss of sovereignty, to dependence and to elimination from the power game.

Seeking the causes of these constructs one should point at, first of all, the transformations occurring in international relations. In fact, international relations adopt some features of internal relations, which is particularly visible in the European Union (Czaputowicz, 2008, p. 33). The changes taking place within a given state are attributed to inevitable consequence of actions aimed at adapting to the international environment (cf. Loś-Nowak, 2013, p. 231). They confirm significant accumulation of (creative and corrective) power located at the international level. This is undoubtedly the potential that often exceeds (in functional and effective aspects) the capacities possessed by particular state entities. As a result of changes, states seek confirmation of their existence by finding themselves in the space of diverse, extended and intensified exchange, which, as it turns out, may only happen in political and economic competition that gives the principle of a country growth its real sense (cf. Foucault, 2010, p. 294). One should also note that the category of relationality is gaining significance, leading to the establishment of an ambiguous imperative of the European balance, manifested in the clash between unanimity and multitude, permeating Europe (cf. Foucault, 2010, pp. 301-303).

Secondly, looking at the case of Poland, an entity which did not have an opportunity to shape the structure of a supranational system but tried to join it, it should be observed that the system had considerable possibilities to influence this entity, especially in the initial adjustment period. What is more, due to the specific situation of Poland, which in the pre-accession period could be described as a relation between the EU and its client, the power of the EU system actually determined the scope of the Polish state sovereignty in the long run, clearly shaping its potential and possibilities.

Thirdly, the activity of Poland in the international system in the communist period was frozen or largely limited due to the dominant position of the USSR in the Eastern Bloc.

Fourthly, in the communist period, societies and economies of the Eastern Bloc countries were also outside the global system. Simultaneously, the communist system created specific rules of functioning, differing from those of capitalist systems. After communism collapsed, the systems 
of this region suddenly found themselves in the sphere of the global system influence and their dysfunctions and lack of competitiveness manifested dramatically. And although the countries started to look for adjustment possibilities both in the economic organization of the market and the corresponding state structure, for a long period of time a significant part of the solutions originating in the post-communist world had been merely attempts at meeting challenges related only to maintaining this new, peripheral status (Staniszkis, 1995, p. 47). This situation was extremely favorable to Western European transnational corporations, which were interested in the transformations taking place in Central and Eastern European countries. Corporations saw opportunities to conquer these attractive markets due to the lack of competition and their high absorption. Therefore, the process of the post-communist countries accession to the EU may be perceived, to a certain extent, in categories of specific annexation (Haller, 2008, p. 141).

However, in spite of everything, we need to emphasize that the offer of the Western states - presented at the beginning of the 1990s and containing a promise of modernization - gave Poland hopes of overcoming this peripheral status. It also became a necessity, as there was no other alternative offered to a country that was somehow isolated from the international system. The offer, however, required the implementation of a number of solutions which were to make the Polish system compatible with the Western structures. By accepting this offer, Poland initially became a client of the Communities and then of the European Union. Since May ${ }^{\text {st }}, 2004$, gradually familiarizing itself with the EU, Poland has been a participant of the integration process, seeking its own place in the integration environment and trying to define its place and role accordingly (cf. Cebul, 2018, p. 428). The consequence of the accelerated transformation, closely tied and dependent on the European integration, was the submission of the internal transformations in Poland, and, in fact, the state-creating processes, to the influence of external supporting and correcting mechanisms. For some political groups this was an objective necessity and the requirement for overcoming the peripheral status, for others - another form of dependence.

In the debate held on $16^{\text {th }}$ of September 2015 (Speeches, 2015) one can easily notice the confrontation between PO and PiS, mainly due to the size of their clubs, although the dichotomy between them was also supported by the views of representatives of other clubs and parliamentary groups. Therefore, the contradictory images of the Union, distinguished in the discourse analysis, should not be treated as belonging only to those two political parties. The analysis reflects only those replies that contained elements of the EU image. For the needs of the survey, particular 
speeches in the parliamentary discussion were assigned a code facilitating the identification of the speaker and the location of their speech in the debate structure ${ }^{1}$.

Table 1. The structure of the Parliamentary discussion held on $16^{\text {th }}$ September 2015

\begin{tabular}{|c|c|}
\hline SPEAKER (CLUB/GROUP) & CODE \\
\hline \multicolumn{2}{|l|}{ SPEECHES } \\
\hline Ewa Kopacz (Prime Minister) & PRM- \\
\hline Grzegorz Schetyna (Minister of Foreign Affairs) & MSZ-W1 \\
\hline Teresa Piotrowska (Minister of Internal Affairs) & MSW- \\
\hline Rafał Trzaskowski (secretary of state in Ministry of Foreign & SSMSZ- \\
\hline Rafał Grupiński (Platforma Obywatelska) & PO-W1 \\
\hline Jarosław Kaczyński (Prawo i Sprawiedliwość) & PiS-W1 \\
\hline Stanisław Żelichowski (Polskie Stronnictwo Ludowe) & PSL-W1 \\
\hline John Abraham Godson (Polskie Stronnictwo Ludowe) & PSL-W2 \\
\hline Tadeusz Iwiński (Sojusz Lewicy Demokratycznej) & SLD-W1 \\
\hline Stanisław Wziątek (Sojusz Lewicy Demokratycznej) & SLD-W2 \\
\hline Ewa Kopacz (Prime Minister) & PRM- \\
\hline Jarosław Gowin (Zjednoczona Prawica) & ZP-W1 \\
\hline \multicolumn{2}{|l|}{ CORRECTION } \\
\hline Jarosław Kaczyński (Prawo i Sprawiedliwość) & PiS-S1 \\
\hline \multicolumn{2}{|l|}{ SPEECHES } \\
\hline Patryk Jaki (Zjednoczona Prawica) & ZP-W2 \\
\hline Piotr Paweł Bauć (Ruch Palikota) & RP-W1 \\
\hline Andrzej Rozenek (Biało-Czerwoni) & BC-W1 \\
\hline Wanda Nowicka (independent MP) & PN-W1 \\
\hline Ludwik Dorn (independent MP) & PN-W2 \\
\hline Zbigniew Girzyński (independent MP) & PN-W3 \\
\hline Łukasz Gibała (independent MP) & PN-W4 \\
\hline Marek Poznański (independent MP) & PN-W5 \\
\hline Armand Kamil Ryfiński (independent MP) & PN-W6 \\
\hline Przemysław Wipler (independent MP) & PN-W7 \\
\hline Marzena Dorota Wróbel (independent MP) & PN-W8 \\
\hline Ryszard Kalisz (independent MP) & PN-W9 \\
\hline Tomasz Górski (independent MP) & PN-W10 \\
\hline \multicolumn{2}{|l|}{ QUESTIONS } \\
\hline Zbyszek Zaborowski (Sojusz Lewicy Demokratycznej) & SLD-P1 \\
\hline Andrzej Kania (Zjednoczona Prawica) & ZP-P1 \\
\hline Tomasz Górski (independent MP) & PN-P1 \\
\hline
\end{tabular}

${ }^{1}$ The structure of codes was standardizes, which greatly simplified the labeling of particular speeches. In every code the first element indicates the role performed by the speaker, for example PO-W1 code tells us that this was a Member of Parliament representing the club of Platforma Obywatelska. The second element of the code informs us about the type of speech: $\mathrm{W}$ - stands for speech, $\mathrm{P}$ - question, $\mathrm{S}$ - correction, $\mathrm{O}$ - reply. On the other hand, the number allows us to single out each speech in the order of the debate. In the reconstructed images this system of codes was used to mark particular speeches. 


\begin{tabular}{|l|l|}
\hline Artur Ostrowski (Sojusz Lewicy Demokratycznej) & SLD-P1 \\
\hline Marzena Dorota Wróbel (independent MP) & PN-P2 \\
\hline Dariusz Joński (Sojusz Lewicy Demokratycznej) & SLD-P2 \\
\hline Marek Domaracki (Sojusz Lewicy Demokratycznej) & SLD-P3 \\
\hline Tadeusz Iwiński (Sojusz Lewicy Demokratycznej) & SLD-P4 \\
\hline Agnieszka Pomaska (Platforma Obywatelska) & PO-P1 \\
\hline Marek Poręba (Platforma Obywatelska) & PO-P2 \\
\hline REPLIES & SSMZS- \\
\hline Rafał Trzaskowski (secretary of state in Ministry of Foreign & SSMSW- \\
\hline
\end{tabular}

Source: Speeches, 2015.

Looking at the contradictory images of the European Union - 1) the EU as a solidarity community vs. 2) the EU as an area of antagonized national interests - we should first of all emphasize that the differences within the elements constructing these images are determined by different ways of understanding the integration process, different methods of participation in the integration project, and thus different scopes of obligations resulting from the membership in the European Union. However, this dichotomy cannot be in any way treated as the reason to assume that Poland's presence in the European Union is questioned by one side of the dispute. Discourse participants consider the European integration to be a value, though admittedly, they perceive it differently.

The image of the EU as a solidarity Community seems to be reconstructed by politicians who feel threatened and insecure as to the possible consequences of the migration crisis to the durability of the European Union. An integral postulate in this image of the Community is the requirement to maintain unanimity in the European Union, to ensure that the EU lasts as a whole. In the narrations included in this set, speakers indicate that in order to overcome this problem we need solidarity, participation and shared responsibility: "we are in this great European Community, but being part of the Community carries obligations" (PRM-W1). The crisis here is a kind of a challenge, a test of durability of integration ties: "we cannot turn our backs to Europe. This is one of the greatest challenges faced by Europe and the European Union right now, this is a challenge which may shake the foundations of the European integration" (SSMSZ-W1). 
The main threats to the unanimity of the European Union, in light of the narrative structures belonging to this category, are particular interests and egotisms inside the EU which are intensified in connection with the migration crisis. According to some MPs they constitute the destructive forces of the integration process: "turning our backs to those who need help (...) accounts for the fact that morally and mentally we withdraw from this Community" (PRM-W1). A similar view was presented by MSZ-W1, who indicated that Poland's task is "to prevent the new division into the West and the East inside the European Union". These fears of possible disintegration and weakening of ties inside the EU can be considered, it seems, as one of the reasons for the PO-PSL government's readiness to accept immigrants. But it should also be noted that the consent in regard to the relocation mechanism is treated as an opportunity for Poland to become visible in the main integration flow: "we are a mature and responsible member of the European Union, helping to solve problems, not causing them (...) we all heard that Poland should pursue (...) more active policies within the European Union. Today, standing aside or turning our backs to this crisis is clearly below our ambition of playing a vital role in the Community and influencing its current policies". Another argument justifying why it is necessary for Poland to support the EU countries affected by the crisis is "the memory of solidarity which the Polish nation received when it needed it from its partners in the European Union (PRM-W1). In this context, PN-W2 Member of Parliament mentions mutuality of obligations: "If within a certain whole we have relationships and interdependencies with others, it is sometimes good to control our immoderate appetites and fears and to reply positively to rational claims, fears and postulates of others, because the principle of reciprocation is valid, (...) I give you so that you could give me, there is reciprocation in services, in solidarity, this is what transactional policy is about". A similar opinion is presented by SSMSZW1, who indicates that "the situation in the east of Europe is unstable", and in the event of "increased migration pressure, the European Union will support us (...) if we look at what is happening in Europe, only totally irresponsible people may want the European Union as the whole to fail to meet this challenge". 
On the other hand, an integral assumption in the narratives classified as belonging to the second set - the EU as an area of antagonized national interests - is the thesis that Poland (its sovereignty) must be defended against the pressure of stronger EU countries and institutions: "to counteract incredible statements of such European politicians as Mr. Schulz. (...) We have the right to defend ourselves against the slander actions taken by deadly enemies of Poland" (PiSW1). In narratives belonging to this set, one cannot find any fears of the EU breakdown due to internal disputes. Admittedly, the migration pressure constitutes a serious external civilization threat, but the crisis is not the cause of intensified particular interests within the EU. Such interests have long been visible - determining some kind of an objective (real) relationship system between the entities composing the European Union. Thus, relocation is not perceived as a test of solidarity inside the EU (as an attempt at saving the community), but as the test of strength (an attempt at consolidating dominance in the EU): "Germany accepted a relatively small group of refugees in Munich, (...) Then Germany closed its border and stopped railway links with its southern neighbors. This is German policy. They say one thing and do another. We are supposed to pay their debts, their debts are to be paid by the Central European countries" (PN-W8). The EU is perceived as an area in which contradictory interests clash. The European Union might stand a chance to become a real community in the future, but this requires changes and significant revaluations in the status of particular entities which compose it. Therefore, the relocation program is perceived as an attempt at imposing unfavorable solutions on Poland and thus questioning its status by the Union: "The European Union pays us, (...) they pay us for giving back to large and strong European countries - because they, not us, decide in Brussels - they took over a significant part of our decisions concerning our matters. They also have great regulatory powers over Poland, these powers have an economic value and a huge political value. We don't get anything for free, we can say they buy it very cheaply from us" (PiS-W1). In this context, speaker PN-W6 also accuses government of favoring the party interests over the national interest: "Prime Minister Donald Tusk wants to be the president of Europe for the second term, therefore Prime Minister Ewa Kopacz has no choice but to join this political correctness and forget about our national interest". 
The narratives included in this group - instead of the thesis that we are obliged to show solidarity with the EU countries affected by the migration crisis - reveal, on the one hand, the formalized understanding of the EU membership: "we should help, (...) but with a safe method, namely financial one. It was mentioned here that it costs 2.8 billion dollars or that is the amount missing in order to maintain the camps from which we have this huge inflow of people into Europe. We can undertake to accept part of this obligation, proportionally to the share of our GDP in the European Union's GDP. It is not high and it will not be a huge amount of money, though it will be a significant sum, anyway" (PiS-W1). On the other hand, the EU, or more specifically, Western European countries are reminded of their obligations towards Poland, including the "betrayal" committed in Yalta. It is clear thus that the actions at the EU level aimed at adopting the immigrant relocation mechanism are perceived as an attempt at confirming/consolidating the peripheral status of Poland: "There is, (...) also this argument (...) Juncker [president of the European Commission in 2014-2019 - K.C] raised it. (...) which refers to the emigration of Poles. Yes, that's true that many, many Poles emigrated, (...) there were those who, especially in the $19^{\text {th }}$ century, fought for your and our freedom, this fight created your obligations towards us, as a land of freedom, not the other way around" (PiS-W1). A similar construction is included in the reply of PN-P2: "Did anyone from the Polish side explain to Mr. Juncker that this huge emigration of Poles to Western Europe, (...) was in fact caused by the betrayal committed by the West, the betrayal of Poland, which took place during the World War Two and just after (...) the war".

As I have already pointed out, the reference point in a discourse analysis lies beyond language. Therefore, drawing our attention to the process of discourse organization, namely frameworks within which meanings are developed and interact with structures (materialization), we need to point at the European Union system. As the analysis shows, all participants at the debate perceive the European Union, or, to be more precise, the structure of ties and interdependencies creating it, as a functional and organic environment for Poland. The EU seems to have certain "magnetic properties". It becomes "a pole of attraction" for Central and Eastern European countries. On the other hand, Western European countries constitute a gradually expanding nucleus of the system, around which concentric circles are developing, marking various levels of economic development and stability (Czaputowicz, 1999, pp. 38-39). The system is perceived here as a set of elements affecting each other, individually and collectively, influencing individuals and teams constituting elements or parts of the system (cf. Dahl, Stinebrickner, 2007, pp. 51-53). Moreover 
- according to our assumptions - systems are not static as they are specific structural processes which undergo transformations (cf. Czyżewski, 49-50).

Returning to the concept developed by Foucault (cf. Foucault, 2010, pp. 301-303), we should observe that the analyzed integration discourse is dominated by symbolic and material clash between unification and multitude, continuously reproduced within the system. It seems that this relationality should be analyzed at least in two approaches. Horizontally, the vision of the EU as solidarity Community (unity) versus the European Union as an area of antagonized national interests (particularism). Vertically, the vision of Poland versus the vision of the EU. In discourse analyses Poland and the EU are treated - as this paper demonstrates - as concepts - containers that debate participants construct within reference points available to them. The shape of these structures, on the other hand, determines the nature and scope of relations between Poland and the European Union.

The clash between unification and multitude observed in this analysis stems from a complex phenomenon of Europeanization - the consequence of joining the European integration process by Member States (cf. Pacześniak, 2014). Progressing transformations in this scope are manifested in the tension between the thesis that states have powers to act independently in the international space and the thesis that their possibilities are determined by the structure of the international system (cf. Czaputowicz, 2009, pp. 29-30). By adopting this perspective we are able to look at Poland as a system, or in fact a sub-system, through which desired efficiency is achieved; efficiency is determined by the potential of the environment and achieved in connections between the state and its external entities - within the integration structure.

Although in political practice independence usually merges with dependence, the observed power (pressure) of the Europeanization process concentrates on considerations whether and to what extent an organized political community possessing a particular potential is able to overcome barriers (cf. Sułek, 2013, p. 49), namely: whether it may develop an ability to transform the environment, or whether the environment defines limits of its capacities, shaping it to a certain degree or even limiting it. Therefore, we can assume that both the direction and consequences of the Europeanization process remain debatable.

The essence of Europeanization lies in including state systems in an interstate system and a supranational process of decision making. Simultaneously, structures are undergoing constant modifications, which gradually build dependencies and the multi-level integrated political system 
in the EU. Therefore, we can observe the top-down flow, from the EU level to the level of particular Member States (Grosse, 2012, p. 10). It should be noted that the European system creates a specific type of rationality (integration pressure) which, within ties and dependencies inside the system, continuously reproduces preference for unity. Unity is an indicator of permanence (validity) of the European Union system, and the fundamental task of each authority is to confirm its subject status. The ability to generate, reproduce and strengthen preferences for the values of the EU system by means of discourse plays a special role here.

The above-mentioned ability is, in fact, the essence of political reign. It ensures integrity of entities operating within a whole, such as the European Union. In this context we can quote the concept developed by PO. MPs from this party treat consistency with the center as an indicator of unity, a synonym of real participation in creating the EU. This vision seems to be highly consistent with the EU system functionality requirements. We should emphasize that this way of qualifying the concept developed by PO does not in any way determine which of the two visions of participation distinguished in the debate (PO versus $\mathrm{PiS}$ ) ensures that our country maintains its subjectivity.

Regardless of this centrifugal force generated by Europeanization (specific integration pressure), integration provides an answer to the growing uncertainty in the globalization space. Therefore, as the analyzed narratives demonstrate, Poland experiences continuous threats and moves to the EU structure, as it offers the possibility of regaining balance. This structure constitutes an offer of political order, thus creating opportunities for regaining lost or threatened subjectivity. As demonstrated above, having joined the integration process, the country may regain its subjectivity, but such subjectivity may turn out to be superficial as the state structure is absorbed by these rational structures. The above-mentioned uncertainty generates different visions of the integration process and different visions of Poland's place and role in the process, presented by particular parties in the debate. The EU became an area and an instrument used in implementing Poland's internal and external policies. Moreover, uncertainty and fears concerning the future (durability) of the integration process, as shown in the analysis of narration structures, can be found in all participants of the Parliament discourse. Therefore, we can see that we think about Poland with reference to the European Union and in relationship with it. For PO the reference point in defining Poland's place and role in the EU is the image of the EU as Community (unity), whereas PiS perceives it as an integration area where particularisms fight to dominate the system. PiS narration structures are 
characterized by seeing internal (certain weaknesses of Poland) and external threats (pressure of the EU, and, above all, pressure exerted by strong Member States). Such threats cause the feeling of entrapment, or are perceived as attempts of external forces to subordinate Poland to the European Union.

The debate analysis proves that competing representations of reality are generated within interdependencies between power systems (Poland versus the EU) or when these two systems clash or merge. One should not forget the specific functional duality of the system, which 1) is both the consequence of simultaneous influence exerted by Poland and the EU on discourse participants, and 2) has the capacity to shape these systems. Discourse may prove their validity, but it may also determine scopes and directions of change. The change of those in power due to election at the domestic level leads to changes to the narration determining vertical relationality: Poland versus the EU. The discourse reveals two ways of participating in the European integration process. PO sees conciliation as a method enabling us to eliminate contradictions between Member States and to join the main integration flow. It is assumed to ensure possibilities of co-participation in creating this process and simultaneously guarantee a position of beneficiary of the European integration. On the other hand, PiS claims it is vital to exhibit Poland's particular interests and to aim at maximizing them by testing the EU tolerance. This approach to participation puts Poland on the fringes of the integration movement dominating the EU. Paradoxically, if we take into account integrity and efficiency of the EU system, to which Poland belongs formally and functionally, this approach might (at least to a certain extent) turn out to be effective.

During the debate a motion was put forward to reject the information of the Prime Minister on the migration crisis in Europe and its repercussions for Poland. The Lower Chamber of the Parliament rejected this motion, thus accepting the information presented by the Prime Minister of the PO-PSL coalition government. 344 MPs took part in the voting. 148 MPs voted for rejecting the information (PiS - 103, SLD - 12, independent MPs - 12, Zjednoczona Prawica - 10, RP - 8, Biało-Czerwoni - 3). 189 MPs (PO - 165, PSL - 21, independent MPs - 3) voted against rejecting the information. 7 MPs abstained from voting, whereas 116 MPs were absent (Voting, 2015).

\section{Conclusions}

The above outlined dichotomy of the images of the Union (their incompatibility and related tensions aggregated by the participation in the integration system, that is, in the system of 
interdependencies) may tempt us to adopt the thesis that such a clear division of the political scene may be dysfunctional (it may weaken Poland in the European Union). However, it seems more cognitively inspiring to treat this dispute as a factor maintaining the topicality and significance of the integration discourse. There is no doubt that the vision of the unanimous and conciliatory European Union gives us the sense of security, but political processes occurring in the EU can be more easily explained in categories of the fight of powers rather than by reference to the Community. Be that is it may, this dispute contributes to some kind of European synthesis (cf. Beck, Grande, 2009, p. 57), which may gradually lead to finding some modus vivendi. Finally, these contradictions should be looked at as some specific form of the being (cf. Pawlikowski, 1952, p. 427).

The dispute between PO and PiS is of prime importance in the analyzed debate. It is the most noticeable element of the debate due to the size of the parliamentary clubs. It should be noted that due to the progressing polarization in the Parliament, the pressure of the state authority striving at establishing the rule of unity is, at least, partially overcome. The Parliament is becoming one of the essential, though not necessarily appreciated, arena on which political dispute is actually held. It is in the Parliament that competitive discourses clash. The status of valid discourse is always granted to the discourse that constitutes the product of authority on the state level (thus being a discourse of the majority - owners of power instruments).

However, the dominance of this discourse - presenting the vision of the place and role of Poland in the EU (which, in turn, is a specific directional predisposition determining activities in the integration area) - can only be partial, since interpenetrating power systems of Poland and the European Union also generate discourse pressure and another confrontation occurs. This time we can observe the clash with the integration discourse (pressure of Europeanization). Admittedly, Poland abandoned its role of the EU "client" and became a co-creator of the integration process. Nevertheless, it still remains an area susceptible to the influence of the Europeanization process, in which the power of state clashes with the integration pressure. Europeanization draws its strength from the potential accumulated in the EU system. Its power also comes from the shift (at least to a certain extent) of subjectivity from the state level to the supranational level. And for the country this means the necessity to achieve functionality and to confirm its status within the European Union system. At the same time it seems that the EU structures may maintain functionality only if the center is able to create conditions for achieving integrity (phasing out 
incoherence) with state entities (whose actions to some extent may appear dysfunctional to the EU system as a whole).

The PO-PSL government accepted the relocation system adopted at the European Union forum in 2015 . However, following the election on $25^{\text {th }}$ October 2015, representatives of the PiS government were obliged to implement policies concerning immigrants (cf. Adamczyk, 2017, p. 308). The PiS government did not give its consent for the acceptance of immigrants within the relocation system (cf. Adamczyk, 2017, pp. 312, 329). Also Hungary refused to participate in the relocation system. Controversies concerning this system adopted a very stormy form, as the refusal coincided with the charges brought by the European Commission and some EU Member States against Poland and Hungary over their violation of the values on which the European Union is based (Kosman, 2017, p. 288). On 23 ${ }^{\text {rd }}$ September 2020 the European Commission presented a new pact on migration and asylum - thus admitting that the previous pact did not meet its expectations and that the European Union was unable to repair it. The new system will be based on cooperation and flexible forms of support offered by particular Member States (Fresh start, 2020).

\section{References}

1. Adamczyk, A. (2017) Kryzys migracyjny w Europie a polska polityka migracyjna. Studia Migracyjne - Przegląd Polonijny, 1, pp. 307-331.

2. Beck, U., Grande, E. (2009) Europa kosmopolityczna: spoleczeństwo i polityka w drugiej nowoczesności. Trans by A. Ochocki. Warszawa: Wydawnictwo Naukowe Scholar.

3. Cebul, K. (2009) Concepts of the European Union in electoral platforms of political parties and parliamentary debates from 2004 to 2008. In Skotnicka-Illasiewicz, E. (ed.) 5 Years of Poland's Membership of the European Union in the Social Context. Warsaw: The Office of the Committee for European Integration, pp. s. 171-199.

4. Cebul, K. (2018) Miejsce $i$ rola Polski w Unii Europejskiej w świetle debat parlamentarnych w Sejmie RP w latach 2004-2011. Warszawa: Wydawnictwo Naukowe UKSW.

5. Czachór, Z. (2006) Przyszłość integracji i systemu Unii Europejskiej: próba prognozy. Athenaeum. Political Science, 14-15, pp. 77-89. 
6. Czaputowicz, J. (1999) Systemowe implikacje integracji europejskiej - znaczenie dla Polski. In Czaputowicz, J. (ed.) Integracja europejska. Implikacje dla Polski. Kraków: Wydawnictwo WAM, pp. 21-42.

7. Czaputowicz, J. (2008) Teorie stosunków międzynarodowych: krytyka i systematyzacja. Warszawa: Wydawnictwo Naukowe PWN.

8. Czyżewski, M. (2010) W stronę teorii dyskursu publicznego. In Czyżewski, M., Kowalski, S. Piotrowski, A. (eds.), Rytualny chaos. Studium dyskursu publicznego. Warszawa: Wydawnictwa Akademickie i Profesjonalne, pp. 49-117.

9. Dahl, R.A., Stinebrickner, B. (2007) Współczesna analiza polityczna. Trans by P. M. Kazimierczak. Warszawa: Wydawnictwo Naukowe Scholar.

10. Duszak, A. (1998) Tekst, dyskurs, komunikacja międzykulturowa. Warszawa: Wydawnictwo Naukowe PWN.

11. Election outcomes (2011) Wyniki wyborów [Online] Available from: https://wybory2011.pkw.gov.pl/wsw/pl/000000.html [Accessed 03/09/2020].

12. Election outcomes (2015) Wyniki wyborów do Sejmu RP [Online] Available from: https://parlament2015.pkw.gov.pl/349_Wyniki_Sejm.html [Accessed 03/09/2020].

13. Election outcomes (2019) Wyniki wyborów 2019 do Sejmu RP [Online] Available from: https://sejmsenat2019.pkw.gov.pl/sejmsenat2019/pl/wyniki/sejm/pl [Accessed 03/09/2020].

14. Fairclough, N., Duszak, A. (2008) Wstęp: krytyczna analiza dyskursu - nowy obszar badawczy dla lingwistyki i nauk społecznych. In Duszak A., Fairclough N. (eds.) Krytyczna analiza dyskursu: interdyscyplinarne podejście do komunikacji społecznej. Kraków: Universitas, pp. 7-29.

15. Fehler, W., Cebul, K., Podgórzańska, R. (2017) Migracje jako wyzwanie dla Unii Europejskiej i wybranych państw członkowskich, Warszawa: Difin.

16. Fleischer, M. (2005) Obserwator trzeciego stopnia: O rozsądnym konstruktywizmie. Trans by D. Wączek, J. Barbacka. Wrocław: Wydawnictwo Uniwersytetu Wrocławskiego.

17. Foucault, M. (2010) Bezpieczeństwo. Terytorium. Populacja. Trans by M. Herer. M. Senellart (ed.). Warszawa: Wydawnictwo Naukowe PWN. 
18. Fresh start (2020) A fresh start on migration: Building confidence and striking a new balance between responsibility and solidarity [Online] Available from: https://ec.europa.eu/commission/presscorner/detail/en/ip_20_1706 [Accessed 10/10/2020].

19. Grosse, T.G. (2012) W objęciach europeizacji. Wybrane przykłady z Europy Środkowej i Wschodniej. Warszawa: Instytut Studiów Politycznych Polskiej Akademii Nauk.

20. Grzegorczykowa, R. (1998) Głos w dyskusji o pojęciu tekstu i dyskursu. In Bartmiński, J., boniecka, B. (eds.) Tekst: problemy teoretyczne. Lublin: Wydawnictwo Uniwersytetu Marii Curie-Skłodowskiej, pp. 37-43.

21. Haller, M. (2008) European Integration as an Elite Process. The Failure of a Dream? New York: Routledge.

22. Kosman, M.M. (2017) Kryzys imigracyjny w UE w latach 2015-2017. Aspekty prawne i polityczne. Rocznik Integracji Europejskiej, 11, pp. 279-294.

23. Laskowska, E. (2004) Dyskurs parlamentarny w ujęciu komunikacyjnym. Bydgoszcz: Wydawnictwo Akademii Bydgoskiej im. Kazimierza Wielkiego.

24. Łoś-Nowak, T. (2013) O potrzebie rekonstrukcji przestrzeni badawczej w nauce o stosunkach międzynarodowych. In Krauz-Mozer, B., Ścigaj, P. (eds.) Podejścia badawcze $i$ metodologie w nauce o polityce. Kraków: Księgarnia Akademicka, pp. 229-243.

25. Maurin, K. (1978) Słowo wstępne. In Weizsäcker, C.F. von Jedność przyrody. K. Maurin (ed.). Trans by K. Napiórkowski et. al. Warszawa: Państwowy Instytut Wydawniczy, pp. $5-28$.

26. Pacześniak, A. (2014) Europeizacja polskich partii politycznych. Warszawa: Wydawnictwo Naukowe Scholar.

27. Paruch, W., Trembicka, K. (2002) Wprowadzenie. In Paruch, W., Trembicka, K. (eds.) Wizje $i$ realia: studia nad realizacja polskiej myśli politycznej XX wieku. Lublin: Wydawnictwo Uniwersytetu Marii Curie-Skłodowskiej, pp. 7-15.

28. Pawlikowski, M. (1952) Dwa światy. Londyn: Veritas.

29. Rapley, T. (2010) Analiza konwersacji, dyskursu i dokumentów. Trans by A. Gąsior-Niemiec. Warszawa: Wydawnictwo Naukowe PWN.

30. Ricoeur, P. (1989) Język, tekst, interpretacja: wybór pism. K. Rosner (ed.). Trans by P. Graff, K. Rosner. Warszawa: Państwowy Instytut Wydawniczy. 
31. Rittel, S.J. (2005) Dyskurs w filozofii politycznej: podejście lingwistycznopolitologiczne i systemowe. Kielce: Wydawnictwo Akademii Świętokrzyskiej.

32. Skotnicka-Illasiewicz, E. (2001) Członkostwo Polski w Unii Europejskiej w kulturze politycznej parlamentarzystów. In Wesołowski, W. (ed.) Obciążeni polityka. Posłowie i partie. Warszawa: Wydawnictwo Instytutu Filozofii Socjologii Polskiej Akademii Nauk, pp. 171194.

33. Speeches (2015) Wypowiedzi na posiedzeniach Sejmu: posiedzenie $\mathrm{nr} 100 \mathrm{w}$ dniu 16-09-2015 (1. dzień obrad) [Online] Available from: http://www.sejm.gov.pl/sejm7.nsf/wypowiedz.xsp?posiedzenie=100\&dzien=1\&wyp=0\&view=1 [Accessed 03/09/2020].

34. Staniszkis, J. (1995) Polityka postkomunistycznej instytucjonalizacji w perspektywie historycznej: część I. Studia Polityczne, 4, pp. 39-60.

35. Staniszkis, J. (2001) Postkomunizm. Próba opisu. Gdańsk: Wydawnictwo Słowo/Obraz Terytoria.

36. Sułek, M. (2013) Potęga państw. Modele i zastosowania. Warszawa: Wydawnictwo Rambler.

37. Szacki, J. (2002) Historia myśli socjologicznej: wydanie nowe. Warszawa: Wydawnictwo Naukowe PWN.

38. Voting (2015) Glosowanie nr 77 na 101. posiedzeniu Sejmu dnia 25-09-2015 ro godz. [Online] Available from: http://www.sejm.gov.pl/sejm7.nsf/agent.xsp?symbol=glosowania\&NrKadencji=7\&NrPosiedzeni $\mathrm{a}=101 \&$ NrGlosowania $=77$ [Accessed 03/09/2020].

39. Waśkiewicz, A. (1998) Interpretacja teorii politycznej: spór o metodę we wspótczesnej literaturze anglosaskiej. Warszawa: Wydawnictwo Naukowe Scholar.

40. Waśkiewicz, A. (2012) Paradoksy idei reprezentacji politycznej. Warszawa: Wydawnictwo Naukowe Scholar.

41. Wiatr, J.J. (2006) Europa pokomunistyczna. Przemiany państw i spoleczeństw po 1989 roku. Warszawa: Wydawnictwo Naukowe Scholar.

42. Zięba, R. (2007) Paradoksy polityki zagranicznej Polski w okresie transformacji. In Karwat, M. (ed.). Paradoksy polityki. Warszawa: Dom Wydawniczy Elipsa, pp. 387-405. 